\author{
ANNA WoJNARSKa \\ Uniwersytet Marii Curie-Skłodowskiej w Lublinie \\ ORCID: 0000-0003-4096-8940
}

\title{
NIEPRZYSTOSOWANIE SPOŁECZNE OSÓB DOROSŁYCH Z ADHD - ASPEKTY DIAGNOSTYCZNE
}

\begin{abstract}
Streszczenie: Celem dokonanego przeglądu badań jest zwrócenie uwagi na specyficzne symptomy ADHD u osób dorosłych i związków ADHD występującego w dzieciństwie z przestępczością w wieku dojrzałym. Przedstawiono modyfikacje kryteriów diagnostycznych oraz opartych na nich metod badania. Stosowanie tylko metod przesiewowych powoduje przeszacowanie lub niedoszacowanie występowania zjawiska ADHD u dorosłych, $\mathrm{z}$ tego powodu wymagana jest rzetelna diagnoza psychiatryczna. Wśród dorosłych z ADHD bardzo często występują dodatkowe zaburzenia, takie jak zaburzenia zachowania, zaburzenia emocjonalne, uzależnienie od alkoholu i/lub narkotyków, zaburzenia osobowości i nasilone trudności w codziennym funkcjonowaniu. Na podstawie rezultatów badań na temat zależności między występowaniem ADHD i przestępczości podejrzewa się, że tylko w przypadku bardzo ciężkiej postaci ADHD wymagającej leczenia farmakologicznego można uznać jej istnienie. W pozostałych przypadkach należy analizować ten problem w kontekście współwystępujących zaburzeń i doświadczeń życiowych. Konieczne jest opracowanie przewodnika diagnostycznego w zakresie ADHD u dorosłych.
\end{abstract}

Słowa kluczowe: ADHD, dorośli, epidemiologia, przestępczość, zaburzenia zachowania, diagnoza

\section{WPROWADZENIE}

Problem funkcjonowania dzieci z ADHD od ponad trzydziestu lat jest często przedmiotem badań psychologicznych i pedagogicznych. Opracowania dotyczą procedury stawiania diagnozy, specyfiki funkcjonowania emocjonalnego, poznawczego i społecznego oraz metod pracy. Brak zainteresowania specjalistów problematyką osób dorosłych z ADHD wynikał z przekonania, że objawy występujące 
w dzieciństwie zanikają w wieku dojrzewania i dorosłości. Jednak współczesne badania wykazują, że pogląd ten nie był słuszny, ponieważ zespół ADHD z wiekiem zmienia swój obraz i jest komplikowany przez nakładające się na symptomy podstawowe dodatkowe zaburzenia. Diagnoza i metody terapii oraz leczenia problemów skojarzonych z ADHD są szczególnie istotne w obszarze oddziaływań resocjalizacyjnych ze względu na dużą częstotliwość jego występowania w grupie osób nieprzystosowanych społecznie. Jednym z podstawowych zagadnień jest rozstrzygnięcie, czy ADHD jest głównym czynnikiem powodującym zachowania ryzykowne i przestępczość, czy raczej powodują je zaburzenia dodatkowe, które często są spowodowane przyczynami psychospołecznymi.

Zespół zaburzeń określany jako ADHD (Atention Deficit Hyperactivity Disorder) jest zaburzeniem zdrowia psychicznego z wyraźnymi objawami w sferze behawioralnej. Symptomy charakteryzujące to zaburzenie są określane w literaturze także jako zespół nadpobudliwości psychoruchowej, zespół minimalnego uszkodzenia mózgu, lekka encefalopatia, wczesnodziecięcy zespół psychoorganiczny (Wolańczyk, Kołakowski, Skotnicka 1999, Kołakowski i in. 2007), zespół hiperkinetyczny, zespół deficytu uwagi z nadruchliwością (Goodman, Scott 2000). Terminologia została ujednolicona w Klasyfikacji Amerykańskiego Towarzystwa Psychiatrycznego (DSM-IV, obecnie DSM-V) oraz w Międzynarodowej Statystycznej Klasyfikacji Chorób i problemów Zdrowotnych, rewizji 10 ( ICD-10), które wprowadziły termin ADHD i sprecyzowały dokładnie kryteria diagnostyczne (Cooper, Ideus 2001).

\section{OBRAZ KLINICZNY ADHD}

W ujęciu DSM-IV oraz ICD-10 objawy nadpobudliwości zostały ujęte w trzy grupy kryterialne dotyczące zaburzeń w koncentracji uwagi, nadruchliwości i impulsywności w zakresie myślenia i emocji. Zwraca się uwagę, że zespół ADHD może być zróżnicowany i nie wszystkie grupy objawów muszą się pojawić, niektóre z nich mogą być dominujące, a pozostałe niezbyt nasilone (Wolańczyk i in. 1999). Objawy te pojawiają się nie później niż w wieku 7 lat, stanowią przyczynę cierpienia subiektywnego i mają charakter całościowy, ujawniający się w różnych sytuacjach. Objawy te mogą mieć różne nasilenie: od stopnia łagodnego do bardzo głębokiego (Goodman, Scott 2000; Cooper, Ideus 2001). Pomiędzy tymi dwoma systemami diagnostycznymi zachodzą jednak istotne różnice. Podobne objawy są zaliczane do innej grupy objawów, ponieważ DSM-IV traktuje nadruchliwość i impulsywność łącznie. Różnica dotyczy także liczby objawów: w DSM-IV wymaganych jest 10 objawów utrzymujących się w ciągu ostatnich 6 miesięcy, podczas gdy w ICD-10 powinno ich wystąpić 12 . Ponadto system DSM-IV różnicuje typy 
nadpobudliwości na podtyp: z przewagą zaburzeń koncentracji uwagi (ADD), $\mathrm{z}$ przewagą nadpobudliwości psychoruchowej oraz mieszany. $\mathrm{Z}$ różnic tych wynikają także konsekwencje dla terapii i leczenia, ponieważ kryteria ICD-10 są bardziej rygorystyczne, co powoduje, że osoby trafiające na leczenie prezentują głębsze i rozleglejsze zaburzenia (Karteczka 2012).

Przedstawione kryteria są dopasowane do rozpoznania ADHD u małych dzieci, natomiast $\mathrm{w}$ przypadku adolescentów i dorosłych brakuje równie precyzyjnych wskazówek diagnostycznych (Sibley i in. 2012). Ponadto objawy podstawowe u dorosłych mogą się manifestować w innych zachowaniach i tak, np. nadruchliwość objawia się głównie w niepokoju ruchowym, impulsywność w drażliwości i podejmowaniu pochopnych decyzji życiowych, problemach w odraczaniu gratyfikacji, natomiast zaburzenia uwagi w niezorganizowanej aktywności często nieprowadzącej do konstruktywnych rezultatów. Zachowania te manifestują się w bardziej subtelny sposób, a zatem są także trudniejsze do wykrycia (Szaniawska 2010).

W modyfikacji systemu DSM-IV, czyli w systemie DSM-V dokonano kilku zmian, m.in. ilość objawów spełniających kryteria rozpoznania ADHD u dorosłych zredukowano z 6 do 4 (http://www.dsm5.org). Postuluje się także zmianę kryterium wieku, podwyższając granicę, do której mogą wystąpić pierwsze objawy, do 12 r.ż. Jest to tym bardziej zasadne, że w Polsce powszechne zainteresowanie diagnozą tego zespołu zaczęło się w latach 90-tych (Szewczuk-Bogusławska, Flisiak-Antonijczuk 2013). Ponadto włączono także zaburzenia ze spektrum autyzmu jako spełniające kryteria ADHD (Kooij i in. 2010), podczas gdy wcześniej były wykluczane.

Na podstawie kryteriów systemu DSM-IV i doświadczeń klinicznych stworzono kilka zmodyfikowanych systemów diagnozy ADHD u osób dorosłych, które uzupełniają listę objawów podstawowych. Przykładem mogą być sformułowane przez Paula Wendera tzw. kryteria UTAH (Wender Utah Rating Scale), które pozwalają określić specyfikę symptomów ADHD u dorosłych. Pierwszym krokiem jest określenie na podstawie diagnozy retrospektywnej czy problemy te ujawniły się już w dzieciństwie. W systemie tym, oprócz podstawowych - czyli nadmiernej aktywności ruchowej i trudności w koncentracji uwagi - podano dodatkowo pięć objawów, z których dwa powinny być spełnione do rozpoznania ADHD. Należą do nich:

- chwiejność emocjonalna charakteryzująca się gwałtownymi biegunowymi zmianami nastroju,

- gwałtowny temperament przejawiający się wybuchami złości i nadmiernym reagowaniem na neutralne bodźce,

- dezorganizacja zachowania, trudność w kończeniu zadań, prokrastynacja,

- niska tolerancja stresu,

- impulsywność (Russell 2000). 
Z czasem kryteria te zmodyfikowano, wprowadzając pięć podstawowych wymiarów $\mathrm{ADHD}$, takich jak aktywacja i organizacja dotyczące inicjowania i organizacji czynności, podtrzymywanie uwagi, energii i wysiłku wyrażające się w osłabionym napędzie, niekonsekwentnym wykonywaniu zadań, zaburzenia w radzeniu sobie z afektem, pamięć operacyjna i dostępność przypominania (Russell 2000).

Natomiast Edward M. Hallowell i John J. Ratey (2004) rozbudowali listę objawów ADHD, dodając do nich następujące kategorie zachowań:

- poczucie braku osiągnięć, niespełnienie własnych celów,

- trudności z organizacją,

- ciągłe odkładanie spraw na później, trudności z rozpoczęciem pracy,

- wiele zadań rozpoczętych jednocześnie, trudności z ich dokończeniem,

- skłonność do mówienia wszystkiego, co przyjdzie do głowy,

- częste szukanie silnych wrażeń,

- paniczny strach przed nudą,

- łatwe rozpraszanie się, „wyłączanie” się, chwiejna uwaga,

- kreatywność, intuicja, inteligencja,

- brak cierpliwości, mała odporność na frustrację,

- impulsywność werbalna lub w działaniu (kompulsywne wydawanie pieniędzy, nagłe zmiany planów, snucie pomysłów na nową karierę),

- skłonność do niepotrzebnego i ciągłego zamartwiania się, jednocześnie niedostrzeganie prawdziwych niebezpieczeństw,

- poczucie niepewności,

- zmiany nastroju, szczególnie w momentach bezczynności,

- pobudzenie - drażliwość w czasie spoczynku,

- skłonność do uzależnień,

- nieprawidłowy obraz „Ja”,

- przypadki depresji lub choroby dwubiegunowej w rodzinie.

National Health Service w Wielkiej Brytanii opracowało następująca listę kryteriów rozpoznawania ADHD u dorosłych:

- nieostrożność i niezwracanie uwagi na szczegóły,

- ciągłe gubienie przedmiotów lub odkładanie na inne miejsce,

- zapominanie,

- ciągłe rozpoczynanie nowych zadań przed ukończeniem wcześniejszych,

- słabe umiejętności organizowania zadań,

- niezdolność skupienia się na jednej rzeczy lub ustalania priorytetów,

- niepokój lub podenerwowanie,

- trudności ze spokojnym czekaniem i mówienie poza kolejnością, impulsywne wypowiedzi i słaba umiejętność dostosowania się do właściwej kolejności podczas rozmowy z innymi, 
- częste przerywanie innym,

- wahania nastroju, drażliwość i wybuchowość,

- brak umiejętności radzenia sobie ze stresem, skrajna niecierpliwość,

- podejmowanie ryzykownych aktywności połączone z poświęcaniem niewielkiej lub żadnej uwagi kwestii bezpieczeństwa własnego lub innych osób (http://www.nhs.uk/conditions/attention-defisit-hyperactivity-disorder/ pages/symptoms.asps za: Moncrieff, Timini 2011, s. 17).

Objawy ADHD u dorosłych można także scharakteryzować w kontekście koncepcji neuropsychologicznej R.A. Barkleya (2009), który zwrócił uwagę na znaczenie procesów hamowania w funkcjach samoregulacji, takich jak pamięć operacyjna, samoregulacja wzbudzenia emocjonalno-motywacyjnego, internalizacja mowy oraz rekonstrukcja. W koncepcji tej podkreśla się znaczenie zaburzonego hamowania, które ujawnia się szczególną podatnością na dystraktory i dużą interferencją działających jednocześnie bodźców. W zakresie pamięci operacyjnej efekt ten jest obserwowalny w podatności na wpływ kontekstu, trudności w utrzymywaniu w pamięci informacji o przeszłości i przyszłości i w zaburzeniach czasowej organizacji czynności. W związku z tym istnieje większe prawdopodobieństwo nieprzestrzegania reguł oraz braku kierowania się nakazami i zakazami nawet przy ich dobrej znajomości. W sferze emocjonalno-motywacyjnej manifestuje się nieprzewidywalnością reakcji emocjonalnych i małą skutecznością działania w sytuacjach stresowych (Borkowska 1999). Takie predyspozycje skłaniają do zachowań antyspołecznych, zachowań negatywistyczno-opozycyjnych, wrogich i agresywnych. Duże znaczenie mają także problemy z internalizacją mowy, która pełni funkcję regulacyjną zachowań społecznych. Mowa pomaga również w odraczaniu gratyfikacji, w kierowaniu się zasadami, posługiwaniu się transferem. Rekonstrukcja oparta na procesach analityczno-syntetycznych dotyczy problemów w planowaniu celowego zachowania i płynności słownej. R.A. Barkley (2009) zwraca uwage na fakt, że osłabione hamowanie wpływa znacząco także na kontrolę motoryczną i uwagę, choć te aspekty nie zostały do końca potwierdzone naukowo.

\section{CZĘSTOŚĆ ADHD WŚRÓD DOROSŁYCH}

Częstość występowania tego zespołu wśród dzieci jest szacowana bardzo różnie, od 1\% w Wielkiej Brytanii, 10\% w Stanach Zjednoczonych do 10-15\% w Polsce (Goodman, Scott 2000, Wolańczyk i in. 1999). Różnice te wynikają najprawdopodobniej ze sposobu diagnozowania. Precyzyjna diagnoza kliniczna obowiązująca w Wielkiej Brytanii daje niższe wskaźniki, około 3-4\%, podczas gdy orientacyjna diagnoza przesiewowa oparta na DSM-IV (DSM-V) znacznie je podwyższa. 
Zdaniem wielu badaczy około $70 \%$ przypadków nadpobudliwości zanika $\mathrm{w}$ okresie dojrzewania w wyniku zachodzących zmian rozwojowych $\mathrm{w}$ budowie i funkcjonowaniu układu nerwowego (Wolańczyk i in. 1999), jednak badania z ostatnich lat wskazują na utrzymywanie się ADHD u dorosłych w postaci odmiennych symptomów. W Wielkiej Brytanii stwierdzono, że u 15\% osób ze zdiagnozowanym ADHD objawy utrzymują się ponad 25 lat, natomiast u 50\% manifestują się one w postaci różnorodnych trudności w codziennym życiu. Wskaźniki ustąpienia objawów ADHD w wieku dojrzałym wahają się od 20 do 57\% (Jackson, Faruggia 1997). W Wielkiej Brytanii częstość występowania tego problemu rozwojowego w ogólnej populacji dorosłych jest szacowana na $1 \%$ (Young i in. 2011), natomiast w Stanach Zjednoczonych na 4-5\% (Fleischmann, Miller 2013, Stein 2008), chociaż i w tym zakresie odnotowuje się duże rozbieżności, od 15 do 20\% (Jackson, Faruggia 1997).

\section{ZABURZENIA TOWARZYSZĄCE ADHD}

W świetle objawowej charakterystyki ADHD można wyróżnić predyktory niedostosowania społecznego, do których należą przede wszystkim impulsywność emocjonalna i behawioralna, wyrażające się w nieprzemyślanych, gwałtownych czynach często o charakterze przestępczym. Nadmierna ruchliwość nieznajdująca akceptowanego społecznie ujścia ujawnia się w bójkach, aktach wandalizmu i przemocy. Trudności w zapamiętywaniu i werbalizacji norm życia społecznego powodują, że pomimo nakazów i zakazów, osoby nadpobudliwe nie potrafią ich stale przestrzegać. Zaburzenia antycypacji nie pozwalają przewidywać konsekwencji własnych czynów i planować własnego zachowania oraz korzystać z własnych doświadczeń. Aktualnie psychiatrzy uważają, że osoby z takimi problemami wg DSM-IV mają podwójny zespół „deficytu uwagi z nadruchliwością oraz zaburzenia zachowania”, natomiast wg ICD-10 „hiperkinetyczne zaburzenie zachowania” F.90 (Goodman, Scott 2000, s. 57). W stosunku do ogólnej populacji ryzyko zachowań antyspołecznych wśród osób z rozpoznanym ADHD jest 10-krotnie większe, 5-krotnie większe jest prawdopodobieństwo uzależnienia się od leków, 25-krotnie - popadnięcia w konflikt z prawem oraz 9-krotnie większe jest prawdopodobieństwo trafienia do więzienia. Stosowany powszechnie w leczeniu nadpobudliwości Ritalin stwarza większą podatność do nadużywania substancji psychoaktywnych, ponieważ ich celem jest również obniżenie pobudzenia, ucieczka od problemów emocjonalnych i subiektywnego cierpienia (Vatz, Weinberg 2001). Edward M. Hallowell i John J. Ratey (http://www.adhd.com 2002) stwierdzili, że około 15 milionów Amerykanów ma zespół ADHD i z tego aż 50\% używa narkotyków, alkoholu lub leków. Joanna Moncrief i Sami Timini (2012) zwracają 
uwagę na fakt, że wiele badań dotyczących ADHD u dorosłych jest sponsorowana przez firmy farmaceutyczne, które są zainteresowane częstym wykrywaniem tego zaburzenia u potencjalnych klientów. Leki psychostymulujące są szybką metodą podnoszenia nastroju i w związku z tym są nadużywane, natomiast badania kliniczne nie potwierdzają ich skuteczności w dłuższej perspektywie czasowej.

Poniższa tabela ilustruje częstość występowania różnych zaburzeń towarzyszących ADHD. Problemem w oszacowaniu skali zjawiska występowania zaburzeń funkcjonowania jest zdefiniowanie normy, do której przyrównuje się konkretne zachowanie. Proponowane podejścia sugerują wybranie jako standardu zachowania typowego w danej grupie rówieśniczej funkcjonowania osoby przeciętnej statystycznie lub osób o porównywanym poziomie intelektualnym. Brak jednoznacznego stanowiska w tym zakresie skutkuje rozbieżnościami w ocenach częstości występowania zaburzeń dodatkowych (Szewczuk-Bogusławska, Flisiak-Antoniuk 2013). Często rozpoznawanie ADHD opiera się na subiektywnej interpretacji objawów osiowych i wynikających z nich zaburzeń funkcjonowania. W przypadku dorosłych wymogi związane z rolami społecznymi są mniej jednoznaczne niż w przypadku dzieci, dlatego trudno jest ustalić kryterium normy (Szaniawska 2010).

Tabela 1. Częstość występowania dodatkowych zaburzeń w grupie osób z ADHD

\begin{tabular}{|l|l|c|}
\hline \multicolumn{1}{|c|}{ Rodzaj zaburzeń dodatkowych } & \multicolumn{1}{|c|}{ Autor, rok } & Częstość (\%) \\
\hline \multirow{2}{*}{$\begin{array}{l}\text { Zaburzenia zachowania, } \\
\text { zachowania opozycyjno-buntownicze }\end{array}$} & Young, Thome 2011 & $40,0-60,0$ \\
\cline { 2 - 3 } & Cooper, Ideus 2001 & 60,0 \\
\cline { 2 - 3 } & Downey i in. 1997 & 41,0 \\
\hline Zachowania destruktywne & Cooper, Ideus 2001 & 45,0 \\
\hline Zachowania antyspołeczne & Barkley 2009 & 25,0 \\
\hline \multirow{4}{*}{ Skłonności depresyjne } & Downey i in. 1997 & 37,0 \\
\cline { 2 - 3 } & Young 2000 & 25,0 \\
\cline { 2 - 3 } & Cooper, Ideus 2001 & 33,0 \\
\hline \multirow{2}{*}{ Uzależnienia od alkoholu } & Downey i in. 1997 & 33,3 \\
\hline \multirow{3}{*}{ Uzależnienia od narkotyków } & Downey i in. 1997 & 20,5 \\
\cline { 2 - 3 } & Hallowey i Rattey 2000 & 50,0 \\
\cline { 2 - 3 } & Jackson, Faruggia 1997 & $14,0-33,0$ \\
\hline \multirow{3}{*}{ Zachowania przestępcze } & Downey i in. 1997 & 12,8 \\
\cline { 2 - 3 } & Jackson, Faruggia 1997 & $20,0-45,0$ \\
\cline { 2 - 3 } & Young 2000b & 33,3 \\
\hline \multirow{2}{*}{ Osobowość antyspołeczna } & Cooper, Ideus 2001 & 25,0 \\
\cline { 2 - 3 } & Jackson, Faruggia 1997 & $5,25,0$ \\
\hline
\end{tabular}




\begin{tabular}{|l|l|c|}
\hline \multicolumn{1}{|c|}{ Rodzaj zaburzeń dodatkowych } & \multicolumn{1}{|c|}{ Autor, rok } & Częstość (\%) \\
\hline Kradzieże & Barkley 2009 & 30,0 \\
\hline \multirow{2}{*}{$\begin{array}{l}\text { Relegacja ze szkoły z powodu zacho- } \\
\text { wania }\end{array}$} & Barkley 2009 & 25,0 \\
\cline { 2 - 3 } & Jackson, Faruggia 1997 & $25,0-35,0$ \\
\hline
\end{tabular}

Źródło: opracowanie własne

W przypadku osób dorosłych problemy te przejawiają się w postaci trudności $\mathrm{w}$ relacjach w miejscu pracy i rodzinie, skłonności do ryzykownego prowadzenia pojazdów, wyższych wskaźników zachowania przestępczego i ryzyka nadużywania substancji psychoaktywnych. Podobne objawy występują u adolescentów z ADHD, którzy ponadto podejmują wczesne kontakty seksualne oraz manifestują symptomy demoralizacji (Sibley i in. 2012, Young i in. 2011). Dorośli z zespołem ADHD istotnie częściej niż ogólna populacja manifestują wyższy poziom zaburzeń depresyjnych i silnego lęku. W grupie tej również częściej pojawiają się próby samobójcze, chociaż wyniki badań w tym zakresie nie są zgodne. Wynika to z trudności w ocenie charakteru, rozległości i głębokości zaburzeń emocjonalnych w różnych etapach życia (Young 2000a, b).

Istotnym czynnikiem ryzyka nieprzystosowania społecznego w tej grupie są niepowodzenia $w$ zakresie edukacji, będące konsekwencją wcześniejszych problemów szkolnych. U dzieci z nadpobudliwością występują trudności w nauce, manifestujące się małą aktywnością w szkole (90\%), kłopotami w czytaniu (20\%), kłopotami w pisaniu (60\%). 30\% uczniów nadpobudliwych nie kończy szkoły, a tylko 5\% kończy college (Cooper, Ideus 2001). Nastolatki z symptomami ADHD często porzucają szkolę, także z powodu relegacji, uzyskują niskie oceny, kończą edukację na poziomie co najwyżej szkoły średniej. W związku z tym jako osoby dorosłe nie podejmują studiów i nie są wykształcone stosownie do wymogów rynku pracy, a to powoduje większe bezrobocie, częstsze zmiany miejsca pracy i niski status socjoekonomiczny. Część z nich, nie będąc w stanie sprostać wymaganiom pracodawców i dyscyplinie w miejscu pracy, decyduje się na samozatrudnienie (18,0\%). Przyczyną trudności w dostosowaniu się do wymagań pracodawcy są uogólnione trudności w relacjach interpersonalnych, które są również widoczne w budowaniu związków partnerskich (Young 2000c; Fleischmann, Miller 2013). Istotnym obszarem, w którym ujawniają się zaburzenia funkcjonowania, jest sfera życia seksualnego. Nastolatki z ADHD podejmują statystycznie wcześniej współżycie seksualne, częściej są narażone na choroby przenoszone drogą płciową i nieplanowaną ciążę, natomiast osoby dorosłe nie potrafią zbudować satysfakcjonujących relacji w tym obszarze, dlatego częściej wdają się w romanse i rozwodzą się (Stein 2008). 
Stwierdzone w dzieciństwie ADHD jest silnym predyktorem wystąpienia zaburzeń osobowości, szczególnie osobowości antyspołecznej w grupie 21-33 latków (Young, Thome 2011, Young 2000b). M. Radochoński (2000) podkreśla, że nadpobudliwość psychoruchowa stanowi sprzyjające podłoże dla kształtowania się osobowości antyspołecznej, którą charakteryzuje brak umiejętności dostosowania się do norm społecznych, impulsywność, lekkomyślność, całkowita nieodpowiedzialność w zakresie systematycznej pracy, brak wyrzutów sumienia, skłonność do oszustwa. Podobną charakterystykę behawioralną osobników podatnych na popełnianie przestępstw o charakterze gwałtownym przedstawił H. Eysenck, opisując neurotycznych ekstrawertyków (Ranschburg 1993).

Z analizy wyników badań można wysnuć wniosek, że jednoczesne występowanie specyficznych deficytów poznawczych, dysfunkcji neuropsychologicznych, agresywnego zachowania i niskich umiejętności społecznych może decydować o pojawieniu się skłonności do zachowań przestępczych (Young 2000c, s. 197). Analiza częstości występowania zaburzeń sprzężonych wskazuje, że występowanie ADHD jest silnie powiązane $z$ różnorodnymi symptomami nieprzystosowania społecznego.

\section{ADHD A PRZESTĘPCZOŚĆ}

Na podstawie międzynarodowych badań wnioskuje się, że wśród osób popełniających przestępstwa częstość występowania objawów ADHD w dzieciństwie sięga aż 71\%, natomiast utrzymywanie się tych objawów w życiu dorosłym odnotowano na poziomie 45\% (Young, Thome 2011). U części przestępców objawy ulegają remisji, lecz u tych, u których się utrzymują, mają one uporczywy i głęboki charakter. Stosując kryteria diagnostyczne DSM-IV, stwierdzono symptomy ADHD u 39\% mężczyzn przestępców (Young i in. 2011a), u 10\% dorosłych kobiet (Rosler i in. 2009) i 45\% u młodocianych (Young i in. 2010). Wskaźniki częstotliwości są modyfikowane przez takie zmienne jak zmienne kulturowe i geograficzne oraz różną metodologie badań. Dodatkowo zmienną podwyższającą ryzyko zachowania przestępczego w tej grupie są deficyty poznawcze, które warunkują impulsywne działanie pod wpływem chwili i presji otoczenia, co powoduje większą wykrywalność tego typu przestępstw (Young, Thome 2011). Więźniowie z ADHD osiem razy częściej są uwikłani w czyny agresywne niż inni więźniowe oraz sześć razy częściej niż ci z osobowością antyspołeczną (Young i in. 2011). Obok uzależnienia od alkoholu i narkotyków oraz lęku, ADHD jest najsilniejszym predyktorem przestępczości w więzieniach.

Chociaż wyniki dotyczące szacowania częstości ADHD w grupie przestępców różnią się, to jednak taki związek może wskazywać na wspólną etiologię tego za- 
burzenia i skłonności do uzależnień od alkoholu i narkotyków, agresji, przemocy i przestępczości (Beaver i in. 2012).

Badanie zależności pomiędzy występowaniem ADHD a przestępczością napotyka na różne przeszkody natury metodologicznej. Istnieje bowiem uzasadniona wątpliwość, czy może, oprócz ADHD, bardziej znaczące są zaburzenia towarzyszące, pojawiające się jako konsekwencja tego zaburzenia neurorozwojowego i/ lub oddziaływań środowiska. Z wyników badań wnioskuje się, że pytanie to jest bardzo trudne do rozstrzygnięcia. Poniższy przegląd badań ilustruje próby badaczy $\mathrm{w}$ zakresie wydzielenia wpływu istnienia ADHD na występowanie przestępczości.

Marianne Mordre i in. (2011) próbowali przeanalizować zależność pomiędzy ADHD a późniejszą przestępczością u osób, które uzyskały takie rozpoznanie w badaniach psychiatrycznych. Dodatkowo zbadano rolę mieszanych zaburzeń, czyli ADHD oraz zaburzeń zachowania i emocjonalnych oraz czynników dodatkowych, głównie rodzinnych. Dobór grupy był niezwykle staranny, a badania miały charakter podłużny, choć w ujęciu historycznym (analizowano biografię badanych). W pierwszym kroku wybrano 541 pacjentów oddziałów psychiatrycznych w wieku 19-41 i dokonano diagnozy weryfikacyjnej na podstawie systemu ICD-10, wyodrębniając zaburzenia ADHD w 46 przypadkach, w pozostałych były to zaburzenia zachowania i inne problemy. W tej grupie 131 (24\%) osób popełniło przestępstwa według Narodowego Rejestru Przestępstw Nowegii. Następnie, metodą regresji wielozmiennowej Coxa, stwierdzono, że predyktorami nasilania się przestępczości w dorosłości są zaburzenia zachowania (56\% wyjaśnianej wariancji), zaburzenia hiperkinetyczne zachowania (54\%) oraz zaburzenia mieszane (33\%), natomiast czynnikami obniżającymi ryzyko były zaburzenia rozwojowe (6\%) i niepełnosprawność intelektualna (3\%). Czynnikami zwiększającymi podatność na wystąpienie przestępczości była płeć (31\%) oraz przewlekłe problemy rodzinne (9\%), takie jak niski poziom socjoekonomiczny i psychopatologia rodziców. Najsilniejszym predyktorem okazały się zaburzenia zachowania, dodanie zaburzeń emocjonalnych ADHD nie podwyższało wskaźników wyjaśnianej wariancji.

Yiva Ginsberg, Tatja Hirkvikoski i Nils Lindefors (2010) również analizowali podobny problem w grupie 315 więźniów zbadanych za pomocą skali Utah i skali samoopisu ASRS (opis w dalszej części artykułu) uzyskując wskaźnik 40\% (134) występowania tego problemu. $\mathrm{Z}$ tej grupy, po dokonaniu dodatkowej diagnozy klinicznej, wybrano 30 więźniów, u których występowało ADHD z współistniejącymi zaburzeniami (zaburzenia nastroju, lękowe, depresja, zespół autyzmu, zespół Aspergera), przy czym tylko dwóch miało postawioną taką diagnozę w dzieciństwie. Wszyscy byli uzależnieni od substancji psychoaktywnych, szczególnie od amfetaminy. Autorzy podkreślali znaczenie rzetelnej diagnozy problemu oraz konieczność dostosowania oddziaływań resocjalizacyjnych do potrzeb więźniów 
z rozpoznanym ADHD. Gisli H. Gudjonsson i in. (2016) z grupy 22226 młodych osób w wieku 14-24 wyłonili na podstawie samoopisu skalą Barkleya osoby, które manifestowały symptomy ADHD, zaburzenia zachowania i były przesłuchiwane przez policję oraz składały fałszywe zeznania. Analiza regresji wykazała, że wiek, płeć, zaburzenia zachowania i symptomy ADHD są istotnymi predyktorami analizowanych kontaktów z policją, przy czym najsilniejszym pojedynczym predyktorem były zaburzenia zachowania oraz ciężkie przypadki ADHD, które wymagały leczenia farmakologicznego.

Międzynarodowy zespół badaczy (Rosler i in. 2004, Retz i in. 2004) zajął się problemem częstości występowania ADHD oraz objawów zaburzeń psychiatrycznych u młodocianych więźniów w Niemczech. W tym celu przebadano 129 osób w wieku 19-21 lat za pomocą skali WURS w celu wykrycia wczesnych symptomów ADHD dzieciństwie, arkusza diagnostycznego Th. Achenbacha diagnozującego zaburzenia eksternalizacyjne i internalizacyjne zachowania na podstawie samoopisu, kwestionariusza impulsywności Eysencka, IPDE (International Personality Disorder Examination) oraz kryteriów DSM-IV i ICD-10 celem potwierdzenia aktualnego występowania symptomów ADHD. Uzyskano wskaźnik częstotliwości ADHD na poziomie $45 \%$ według kryteriów DSM-IV, natomiast $21,5 \%$ według kryteriów ICD-10. Osoby z zaburzeniami uwagi w $64 \%$ posiadały również symptomy zaburzeń psychiatrycznych z co najmniej 2 zespołów, tylko jedna osoba nie miała diagnozy psychiatrycznej. W wyłonionej grupie osób z potwierdzoną diagnozą ADHD w porównaniu $\mathrm{z}$ więźniami bez takiego rozpoznania dominowały zaburzenia internalizacyjne, alkoholizm i narkomania, wysoki neurotyzm, niska ugodowość i sumienność. Ponadto stwierdzono istnienie w rodzinach osób badanych czynników ryzyka przestępczości w postaci niskiego poziomu socjoekonomicznego, niepełnej rodziny, patologii (alkoholizmu, przestępczości, przemocy).

Michael Rosler i in. (2009) podjęli również próbę diagnozy występowania ADHD u kobiet, które popełniły przestępstwa. W tym celu przebadano za pomocą niemieckiej adaptacji WURS oraz kryteriów DSM-IV 110 osadzonych kobiet, co pozwoliło na wyłonienie grupy 11 spełniających kryteria. $\mathrm{W}$ rezultacie stwierdzono, że kobiety z ADHD wchodzą w konflikt z prawem we wcześniejszym wieku, ich kariera przestępcza trwa dłużej niż osadzonych niespełniających tych kryteriów ADHD. Pomiędzy tymi dwoma grupami nie było natomiast różnic w zakresie zaburzeń osobowości depresyjnych, maniakalnych, lękowych natomiast były istotne różnice w zakresie zaburzeń osobowości typu borderline oraz zaburzeń odżywiania oraz nadużywania substancji psychoaktywnych, szczególnie amfetaminy, na niekorzyść przestępczyń z ADHD (85,5\% badanych).

Powyższy przegląd wskazuje na trudność w realizacji badań, które pozwalałyby z dużym prawdopodobieństwem orzec, że ADHD jako pojedynczy czynnik 
decyduje o pojawieniu się przestępczości. Podstawową trudnością jest dobór, który - jak widać - musi być wieloetapowy, począwszy od retrospektywnej diagnozy ADHD w dzieciństwie, poprzez aktualne potwierdzenie objawów za pomocą obserwacji lub samoopisu i diagnozę psychiatryczną. Nie zawsze jest to możliwe do zrealizowania, tym bardziej, że przestępcy często wywodzą się z rodzin, gdzie nie zadbano o odpowiednią dla nich pomoc psychologiczno-pedagogiczną $\mathrm{w}$ dzieciństwie. $\mathrm{Z}$ tego powodu w populacji przestępców trudno jest wyodrębnić „Czyste” przypadki ADHD. Ponadto czynnikami mediującymi pomiędzy ADHD a przestępczością wydają się być zmienne rodzinne, które mierzone były tylko na podstawie ankiet retrospektywnych, co zawsze rodzi wątpliwość co do rzetelności. Natomiast niewątpliwie rodziny, z których wywodzą się przestępcy z objawami ADHD, to rodziny niewydolne wychowawczo, dysfunkcjonalne i patologiczne ze względu na występowanie przestępczości, alkoholizmu i bezrobocia. Również doświadczenia przemocy i związane z tym zaburzenia posttraumatyczne mogą być czynnikami w największym stopniu odpowiedzialnymi za uruchomienie kariery przestępczej. Wskaźnik dziedziczenia objawów ADHD (50-70\%) wskazuje, że prawdopodobnie rodzice takich dzieci sami manifestowali różnorodne i rozległe problemy w socjalizacji, a zatem dziedziczenie problemów było również uwarunkowane modelowaniem (Beaver i in. 2012, Becker i in. 2017).

Ograniczenia badań dotyczą także rekrutacji osób, ponieważ często są to osoby pochodzące z jednej instytucji, co utrudnia generalizację wniosków ze względu na brak reprezentatywności próby. Z pewnością barierą w uzyskaniu danych wrażliwych jest obecnie wprowadzona w Polsce ustawa RODO, a wcześniej Ustawa o ochronie danych osobowych. Ponadto, dokonując rzetelnej diagnozy ADHD, cytowani badacze uzyskiwali stosunkowo małe grupy, co powodowało osłabienie siły stwierdzonych statystycznie zależności. Trudność w zakresie porównywania wyników badań wynika także z różnorodności stosowanych technik diagnostycznych i sposobu dotarcia do danych biograficznych.

\section{PROBLEMY W DIAGNOZIE ADHD}

Podstawą udzielenia właściwej pomocy dziecku z ADHD jest sporządzenie właściwej diagnozy klinicznej, która powinna mieć charakter interdyscyplinarny. Punktem wyjścia jest szczegółowa diagnoza lekarska, uwzględniająca ogólny stan zdrowia dziecka i - o ile jest to możliwe - badania neurologiczne. W ustaleniu rozpoznania ważne jest skonfrontowanie opinii rodziców i nauczycieli, które pozwala stwierdzić, czy trudności mają charakter uogólniony i trwały. Poza tym konieczne jest przeprowadzenie klinicznej diagnozy psychologicznej ze zwróceniem uwagi na 
przejawy zaburzeń hamowania w procesach umysłowych (Wolańczyk i in. 1999, Cooper, Ideus 2001). Dopiero takie dane wyjściowe upoważniają do sporządzenia diagnozy klasyfikacyjnej. W praktyce bardzo często diagnoza ma charakter przesiewowy i sporządzana jest tylko przez nauczyciela, przez co głównie wyłaniane są dzieci nadpobudliwo-impulsywne podczas gdy impulsywno-nieuważne są wykluczane $\mathrm{z}$ takich ocen. Taki sposób diagnozowania ADHD powinien dotyczyć adolescentów i osób dorosłych.

Podobnie jak w przypadku dzieci, konieczne jest uzyskanie informacji od rodziców i nauczycieli dotyczących wczesnego okresu rozwojowego celem określenia, kiedy pojawiły się symptomy i w jakiej postaci. W praktyce jest to bardzo trudne, ponieważ rodzice, często sami z problemami w socjalizacji, nie są w stanie przypomnieć sobie tych ważnych faktów. Nauczyciele szkół ponadpodstawowych często znają uczniów słabiej niż nauczyciele pierwszych klas szkoły podstawowej, ponieważ w nauczaniu przedmiotowym spędzają zaledwie kilka godzin. Natomiast bazowanie na subiektywnym opisie swoich trudności przez samą młodzież jest mało wiarygodne ze względu na przytoczone przez Barkleya (2009) specyficzne cechy funkcjonowania psychicznego. Rzeczywiście próby zestawienia tych źródeł informacji w przypadku młodzieży wykazały dużą rozbieżność ocen rodziców i nauczycieli oraz danych samoopisowych i ocen rodziców (Sibley i in. 2012). Trudności te mogą skutkować albo rozpoznaniem problemu rozwojowego tam, gdzie go nie ma, albo brakiem spełnienia kryteriów ze względu na niewystarczającą wiedzę informatorów.

Najczęściej stosowane w badaniach kwestionariusze samoopisowe są oparte na kryteriach DSM-IV i powinny być traktowane głównie jako metody przesiewowe. Metody te mogą być niewiarygodne, ponieważ często mylne rozpoznanie u siebie objawów wynika z wiedzy osób dorosłych na temat problemu ADHD czerpanej z literatury lub mediów, co powoduje przypisywanie sobie symptomów tego zaburzenia. Susan Young (2000b) zwraca uwagę na fakt, że osoby dorosłe są zainteresowane uzyskaniem takiej diagnozy, ponieważ stanowi ona usprawiedliwienie życiowych niepowodzeń oraz daje szansę uzyskania leczenia środkami poprawiającymi nastrój. Duże znaczenie rosnącej od lat 90-tych popularności rozpoznania ADHD u dorosłych odgrywają koncerny farmaceutyczne, które są zainteresowane zwiększeniem sprzedaży leków psychostymulujących (Moncrieff, Timini 2011). Takie działania powodują przeszacowanie częstości ADHD u dorosłych, natomiast $\mathrm{z}$ drugiej strony pojawia się także tendencja do niedoszacowania problemu. U wielu nadpobudliwych dorosłych obserwuje się czasową i częściową remisję objawów, a brak ich zdolności do monitorowania własnego zachowania i refleksji nie pozwala im dostrzec tych zmian (Russell 2000). Badania przesiewowe, np. wśród studentów (Garnier-Dykstra i in. 2010), ujawniają, że problem 
występowania ADHD u dorosłych jest niedoszacowany, ponieważ w grupie 1080 studentów bez wcześniejszego rozpoznania aż 10,3\% uzyskało wyniki wysoce świadczące o spełnieniu kryteriów ADHD. Szansą na dokonanie takiej wstępnej diagnozy jest skorzystanie $\mathrm{z}$ dostępnych $\mathrm{w}$ Internecie rekomendowanych przez profesjonalistów kwestionariuszy samoopisowych, choć w tym zakresie zaleca się ostrożność, ponieważ działania marketingowe zarówno firm farmaceutycznych jak i prywatnych klinik i gabinetów mogą skłaniać do rozpoznania problemu tam, gdzie go nie ma.

Wśród skal bazujących tylko na samoopisie lub samoopisie i obserwacji zachowań przez osoby bliskie stosowanych w badaniach naukowych znajdują się m.in.:

- ASRS - ADHD Rating Scale oraz skrócona na podstawie analizy regresji sześciopunktowa World Health Organisation Adult ADHD Self-Report Scale dostępne w wielu językach (http://www.hcp.med.harvard.edu/ncs/ asrs.php). Składa się ona z 18 punktów bazujących na kryteriach DSM-IV ocenianych na skali 1-3 (czasami, często, bardzo często), wyniki końcowe 0-3 oceniane są jako niskie, 4-8 poważne, powyżej 9 jako kliniczne (Garnier-Dykstra i in. 2010).

- The Brown ADD Scale Diagnostic Form (BADS) mierząca tylko te zachowania, które odnoszą się do funkcji wykonawczych i nieuważności.

- The Conners Adult ADHD Rating Scale posiadająca wersję dla nauczycieli, rodziców, młodzieży i dorosłych, rozbudowaną i skróconą. W Polsce opracowana jest wersja Conners 3 przeznaczona do badania dzieci i młodzieży w wieku 6-18 lat (Wujcik, Wrocławska-Warchała, 2016).

- WURS - Wender Utah Rating Scale, która zawiera również diagnozę zaburzeń towarzyszących (Koopij S. i in. 2010 za: Ginsberg i in. 2010).

- BCS Barkley Current Symtoms Scale - zawiera 18 itemów ocenianych na skali 4-punktowej odzwierciedlającej występowanie symptomu w ciągu ostatnich 6 miesięcy. Rozpiętość punktacji mieści się w przedziale 0 do 27 w każdej podskali (nieuwaga, hiperaktywność/impulsywność) i 0-54 dla całej skali (Gudjonsson i in. 2016).

- DIVA - Diagnostic Interview for ADHD in Adult (http://www.divacenter. eu/content).

- ADHD Samotest dla dorosłych (http://www.ads-bei-erwaschsenen.de/).

- Skala zaburzenia uwagi w arkusz diagnostycznym TRF (Teacher's Report Form) Thomasa M. Achenbacha dla dzieci i młodzieży (Urban 2000).

Trafność rozpoznania problemu ADHD u dorosłych może być podniesiona poprzez zastosowanie pytań ze skal samoopisowych jako składnika wywiadu klinicznego. Ze względu na trudności w dotarciu do danych retrospektywnych, zalecane jest wykorzystanie informacji od osób dobrze znających życie badane- 
go, czyli rodziców, innych członków rodziny, przyjaciół, partnerów życiowych, współpracowników. Pytania powinny mieć charakter otwarty i dotyczyć obszarów, w których ujawniają się trudności i odmienności funkcjonowania (Jackson, Farrugia 1997). Narzędziem pogłębionej diagnozy opartej na samoopisie może być także wywiad częściowo ustrukturalizowany, zawierający pytania otwarte lub półotwarte dotyczące oceny swojej sytuacji życiowej aktualnej i przeszłej, poczucia tożsamości, obrazu ja i oczekiwań wobec przyszłości (Young 2000c).

W badaniach osób dorosłych w Stanach Zjednoczonych wykorzystywane najczęściej są skale, które, oprócz diagnozowania objawów ADHD, koncentrują się na ocenie subiektywnego poczucia jakości życia. Do tej kategorii metod należą The Adult ADHD Quality of Life Scale i The Weiss Functional Impairement Rating Scale - Self Report (WFIRS-S) mierząca subiektywne spostrzeganie zaburzeń w zakresie życia rodzinnego, zawodowego, szkolnego, obrazu „Ja”, relacji społecznych i ryzyka (Stein 2008).

Rzetelne rozpoznanie ADHD powinno bazować na pełnej diagnozie klinicznej (Beaver i in. 2012, Young 2000b). W przypadku osób dorosłych często na objawy związane z ADHD nakładają się zaburzenia wynikające z doświadczeń życiowych, takich kumulacja frustracji, poczucie winy, odrzucenia, samotności i niezrozumienia przez otoczenie (Stein 2008). Główną trudność w diagnozie ADHD u dorosłych sprawia odróżnienie objawów wynikających z istoty zaburzenia (pierwotnych) od objawów towarzyszących, wynikających chociażby z doświadczeń życiowych (wtórnych) i/lub współwystępowania zaburzeń psychiatrycznych, takich jak osobowość borderline, antyspołeczna, choroba afektywna dwubiegunowa I lub II typu, cyklotymia, depresja, uzależnienia, lęk uogólniony, OCD, objawy prodromalne schizofrenii, wczesny początek choroby Alzheimera, następstwa urazów głowy (Szaniawska 2010, s. 208; Russell 2000). Przedmiotem interdyscyplinarnej diagnozy klinicznej powinno być także wykluczenie, podobnie jak u dzieci, istnienia chorób somatycznych lub zespołu stresu pourazowego (PTSD). Ponadto wymienione $\mathrm{w}$ kryteriach diagnostycznych trudności w codziennym funkcjonowaniu charakteryzują większość osób dorosłych, są ich naturalnymi cechami, natomiast w przypadku osób z ADHD kryterium różnicującym jest ich nasilenie i uporczywość (Szaniawska 2010).

W związku z ograniczeniami w stosowaniu kwestionariuszy, pojawiają się metody alternatywne, oparte również na samoopisie. Należy do nich analiza narracji w odniesieniu do własnego życia, doznawanych niepowodzeń i sposobów radzenia sobie z nimi. A. Fleischmann i E.C. Miller (2013) przeprowadzili badania, w których oparli się na metodologii analizy monologu zaproponowanej przez Labova i Waletzkiego (Ellliot 2005 za: Fleischmann, Miller 2013), wyodrębniając następujące aspekty: 
- abstrakt - dotyczy głównego tematu monologu,

- ukierunkowanie - opis warunków zdarzeń, głównych bohaterów, aktualnej sytuacji,

- $\quad$ komplikacje - wyjaśnienie sekwencji zdarzeń i doprecyzowanie krytycznej aktywności, która miała decydujące znaczenie dla historii,

- ocena - dotyczy znaczenia, jakie autor przypisuje zdarzeniom,

- konkluzja - precyzuje wyniki historii,

- skierowane do czytelnika w chwili teraźniejszej i wskazanie, co zdarzy się wkrótce.

Analizie poddano 40 historii życia osób dorosłych, publikujących swoje historie na ogólnodostępnych stronach internetowych. Główne problemy wyłaniające się z tych zwierzeń wskazują na silne skłonności do obwiniania się za niepowodzenia życiowe, co wpływało na obniżenie samooceny i samoakceptacji. Ponadto badani podkreślali znaczenie wczesnej i trafnej diagnozy, która, dokonana w odpowiednim momencie, pozwoliłaby zrozumieć własne trudności w kategoriach specyfiki rozwoju i zdjęłaby odpowiedzialność za niedostosowane zachowania, a ponadto dałaby szansę na uzyskanie adekwatnej pomocy. Badania te ujawniły także, że w osobach z symptomami ADHD tkwi duży rozwojowy potencjał, który ma szansę ujawnić się w sprzyjających warunkach. Podsumowując te wnioski, zwrócono uwagę, że w ujęciu salutogenetycznym prezentowane historie życiowe mogą pomóc ludziom, którzy borykają z problemami wynikającymi z ich zaburzonego rozwoju i wskazać drogę ich pokonania, a przede wszystkim dają nadzieję, że jest to możliwe (Fleischmann, Miller 2013).

\section{PODSUMOWANIE}

Dokonany przegląd wyników badań i analiz teoretycznych skłania do sformułowania kilku wniosków.

Udowodnione utrzymywanie się objawów ADHD u osób dorosłych wymaga opracowania przewodnika diagnostycznego uwzględniającego specyfikę objawów w tej grupie i wśród adolescentów (Sibley i in. 2012). Pożądane byłoby dokonanie zweryfikowania pod względem dobroci psychometrycznej stosowanych w badaniach indywidualnych i grupowych metod i być może, przy współpracy specjalistów $z$ różnych krajów, sporządzenie stosownych rekomendacji. Stworzyłoby to szansę na porównanie wyników w różnych kontekstach kulturowych i doprecyzowanie wskaźników częstości występowania ADHD. Niestety bazowanie tylko na metodach przesiewowych (skryningowych) daje w efekcie zbyt częste lub zbyt rzadkie rozpoznawanie ADHD u dorosłych (Szaniawska 2010). Przewodnik diagnostyczny 
powinien zawierać wskazania dotyczące diagnozy różnicowej i kryteriów wykluczania wątpliwych przypadków ADHD (Russell 2000).

Pewne niebezpieczeństwa związane są z popularyzacją wiedzy na temat ADHD, która ukierunkowuje osoby badane na rozpoznanie problemu u siebie. Ponadto takie rozpoznanie niesie ze sobą konkretne korzyści, polegające na przerzuceniu odpowiedzialności za własne niepowodzenia w różnych sferach na deficyt rozwojowy, obniżeniu motywacji do zmiany i uzasadnieniu potrzeby korzystania z leków podwyższających nastrój. Budzącym wątpliwości co do trafności diagnozy jest fakt zwiększania się liczby kobiet w populacji dorosłych osób z ADHD (Moncrieff, Timini 2011).

W odniesieniu do zależności pomiędzy występowaniem symptomów ADHD a przestępczością, wyniki badań nie udzielają jednoznacznej odpowiedzi ze względu na trudności wykluczenia dodatkowych zaburzeń towarzyszących oraz kontekst sytuacyjny i doświadczenia życiowe. Niewątpliwie potwierdzone są wskaźniki podwyższonej częstości występowania tego problemu rozwojowego w grupie przestępców i występowania przestępczości w grupie osób z ADHD. Natomiast analizy wykazują, że tylko ciężkie przypadki ADHD wymagające leczenia farmakologicznego oraz ADHD w powiązaniu z zaburzeniami zachowania, uzależnieniami, zaburzeniami osobowości i płcią są predyktorem wykolejenia przestępczego (Mordre i in. 2011, Retz i in. 2004, Rosler i in. 2004).

Ze względu na konieczność uwzględnienia tego problemu rozwojowego, pożądane byłoby opracowanie ekonomicznej metody skryningowej dla sądownictwa (Young i in. 2011). Pozwoliłoby to na dostosowanie oddziaływań resocjalizacyjnych do potrzeb sprawców przestępstw i być może obniżenia wskaźnika recydywy (Young i Thome 2011). Diagnoza dla potrzeb resocjalizacji wymaga koordynacji współpracy wydziału zdrowia, służb socjalnych i sądownictwa (Young i in. 2011).

$\mathrm{Na}$ zakończenie warto jednak podkreślić, że wielu dorosłych z objawami ADHD doskonale kompensuje trudności wynikające $\mathrm{z}$ tego zaburzenia. Takie cechy jak inteligencja i kreatywność pozwalają osiągnąć sukces w zawodach wymagających niekonwencjonalnego funkcjonowania. Samodyscyplina i rozwijanie refleksyjności pomagają łagodzić skutki impulsywności w zakresie podejmowania decyzji życiowych. Natomiast zrozumienie istoty trudności i wsparcie emocjonalne ze strony otoczenia skutecznie zapobiegają kumulowaniu się czynników ryzyka nieprzystosowania społecznego. Wczesna diagnoza i terapia pozwalają zapobiec pojawieniu się zaburzeń towarzyszących w wieku dorosłym, a także opracować strategie radzenia sobie z trudnościami wynikającymi z deficytu rozwojowego. 


\section{LITERATURA}

Barkley R.A., 2009, ADHD. Podjąć wyzwanie. Poznań, Zysk i Ska.

Beaver K.M., Nedelec J.L., Rowland M.W., Schwartz J.A., 2012, Genetic Risk and ADHD Symptomatology: Exploring the Effects of Parental Antisocial Behaviors in an Adoption-Based Study. "Child Psychiatry and Human Development”, 43, s. 293-305. DOI: 10.1007/s10578-011-0263-0.

Becker St.P., Mahari K.R., Langberg J.M., Evans St.W., 2017, Rates of peer victimization in young adolescents with ADHD and associations with internalizaing symptoms and self-esteem. „European Child and Adolescent Psychiatry”, 26, s. 201-214. DOI: 10.1007/s00787-016-0881-y.

Borkowska A., 1999, Nadpobudliwość psychoruchowa w neuropsychologicznej koncepcji Russella A. Barkleya. W: Neuropsychologia emocji. Poglądy Badania Klinika. Lublin, UMCS, s. 163-190.

Cooper P., Ideus K., 2001, Zrozumieć dziecko z nadpobudliwościa psychoruchową. Warszawa, APS.

Downey K.K., Stelson F.W., Pomerleau O.F., Giordani B., 1997, Adult attention deficit hyperactivity disorder: Psychological test profils in clinical population. „Journal of Nervous and Mental Disease", 1, s. 1-7.

Fleischmann A., Miller E.C., 2013, Online Narratives by Adult With ADHD Who Where Diagnosed in Adulthood. „Learning Disability Quartely”, 31(1), s. 47-60. DOI: $10.1177 / 0731948712461448$.

Garnier-Dykstra L.M., Pinchevsky G.M., Caldeira K.M., Vincent K.B., Arria A.M., 2010, Self-reported adult attention-deficyt / hyperactivity disorder symptoms among college students. "Journal of American College Health”, 39, 2, s. 133-136.

Ginsberg Y., Hirvikoski T., Lindefros N., 2010, Attention Deficit Hyperactivity Disorder (ADHD) among longer-term prison inmates is a prevalent, persistent and disabling disorder. „BMC Psychiatry”, 10, s. 112. http://www.biomedcentral.com/1471$244 X / 10 / 112$.

Goodman R., Scott S., 2000, Psychiatria dzieci i młodzieży. Wrocław, Wydawnictwo Medyczne Urban\& Partner.

Gudjonsson G.H., Sigurdsson J.F., Sigfusdottir I.D., Asgeirsdottir B.B., Gonzales R.A., Young S., 2016, A national epidemiological study investigation risk factors for police interrogation and false confession among juveniles and young person. „Social Psychiatry and Psychiatry Epidemiology”, 51, s. 359*-367. DOI: 10.1007/ s00127-015-1145-8.

Hallowell E.M., Ratey J.J., 2004, W świecie ADHD. Poznań, Media Rodzina.

Jackson B., Faruggia D.,1997, Diagnosis and treatment of adults with attention deficit hyperactivity disorder. „Journal of Counselling and Development”, 75, s. 312-319. 
Karteczka K., 2012, Zespół hiperkinetyczny (ADHD) u osób dorosłych. „Edukacja Dorosłych", 1, s. 113-126.

Kooij S.J.J., Bejerot S., Blackwell A., Caci H., Casas-Brugue M. i in., 2010, European cocnsensus statement on diagnosis and treatment of adult ADHD: The European Network Adult ADHD. „Psychiatry”, 10, s. 67. http://www.biomedcentral.com/1471-244X/10/67

Kołakowski A., Wolańczyk T., Pisula A., Skotnicka M., Bryńska A., 2007, ADHD zespól nadpobudliwości psychoruchowej. Gdańsk GWP.

Mordre M., Groholt B., Kjesberg E., Sandstad B., Mythre A.M., 2011, The Impact of ADHD and Conduct Disorder in Childhood on Adult Deliquency: A 30 Years Follow-Up Study Using Official Crime Records. „BMC Psychiatry”, 11, s. 57. http:// www.biomedcentral.com/1471-244X/11/57

Moncrieff J., Timini S., 2011, Krytyczna analiza koncepcji nadpobudliwości psychoruchowej z zaburzeniami uwagi u dorostych. „The Psychiatrist”, 35, s. 334-338.

Radochoński M., 2000, Osobowość antyspołeczna. Rzeszów, Wydawnictwo WSP.

Ranschburg J.,1993, Lęk, gniew, agresja. Warszawa WSiP.

Retz W., Retz-Juninger P., Hengersch G., Schneider M., Thome J., Pajonik F., SalahiDisfan A., Rees O., Wender P.H., Rosler M., 2004, Psychometric and psychopathological characterization of young male prison inmates with or without attention deficit/ hyperactivity disorder. „European Archives of Psychiatry and Clinical Neuroscience”, 254, s. 201-208. DOI: 10.1007/s00406-004-0470-9.

Rosler M., Retz W., Retz-Juninger P., Hengesch G., Scneider M., Supprian T., Schwitzgebel P., Pinhard K., Dovi-Akue N., Wender P., Thome J., 2004, Prevalence of attention deficit/hyperactivity disorder (ADHD) and comorbid disorders in young male prison inmates. „European Archives of Psychiatry and Clinical Neuroscience”, 254, s. 365-371. DOI: 10.1007/s0406-004-1516-Z

Rosler M., Retz W., Yaqoobi K., Burg E., Retz-Juninger P., 2009, Attention deficit/ hyperactivity disorder in female offenders: Prevalence, psychiatric comorbidity and psychosocial implications. „European Archives of Psychiatry and Clinical Neuroscience”, 259, s. 98-105. DOI: 10.1007/s00406-008-0841-8

Russell S.H., 2000, Adult ADHD: Evaluation and Treatment in Family Medicine. „American Family Physician”, 62 (9), s. 2077-2086.

Sibley M.H., Pelham W.E., Gnagy E.M., Waschbusch D.A., Kuriyan A.B., Babinski D.E., Molina B.S.G., Garefino A.C., Karch K.M., 2012, Diagnosing ADHD in adolescence. „Journal of Counsulting and Clinical Psychology”, 80, 1, s. 139-150. DOI: 10.1037/a0026577.

Stein M.A., 2008, Impairment associated with adult ADHD. „Primary Psychiatry”, 15, 8 (suppl 4), s. 9-11.

Szaniawska M., 2010, Trudna diagnoza - dylematy rzetelnej oceny ADHD u dorostych pacjentów. Część I. Obraz kliniczny, trudności diagnostyczne, leczenie. „Psychiatria Polska”, 10, 3, s. 205-210. 
Szewczuk-Bogusłąwska M., Flisiak-Antonijczuk H., 2013, Czy zmiana kryteriów ułatwi rozpoznanie ADHD u dorosłych? „Psychiatria Polska”, 47, 2, s. 293-302.

Urban B., 2000, Zaburzenia w zachowaniu i przestępczość młodzieży, UJ Kraków.

Wolańczyk T., Kołakowski A., Skotnicka M., 1999, Nadpobudliwość psychoruchowa u dzieci. Lublin.

Wujcik R., Wrocławska-Warchała E., 2016, Conners. Podręcznik. Pracownia Testów Psychologicznych, Warszawa.

Young S., 2000a, ADHD children grown up: an empirical review. „Counselling Psychology Quartely", 3, 13, s. 191-200.

Young S., 2000b, Attention deficit hyperactivity disorder in adults: clinical issues. A report from the First NHS Clinic in the UK. „Counselling Psychology Quartely”, 13, 3, s. 313-340.

Young S., 2000c, A qualitative study exploring the life-course of young offenders with symptoms and signs of ADHD who were detained in a residential care setting. „Criminal Behaviour and Mental Health”, 19, s. 54-63.

Young S., Adamou M., Bolea B., Gudjonsson G., Muller U., Pitts M., Thome J., 2011, The identification and management of ADHD offenders within criminal justice system: a consensus statement from UK adult ADHD network and criminal justice agencies. „BMC Psychiatry”, 11, 32. http://www.biomedcentral.com/1471-244X/11/32 Young S., Thome J., 2011, ADHD and offenders. „The World Journal of Biological Psychiatry", 1281, s. 124-128. DOI 10.3109/15622975.2011.600319

Vatz R.E., Weinberg L.S., 2001. Problems in diagnosing and treating ADD/ADHD. „USA Today Magazine”, 129, s. 64-66.

\section{NETOGRAFIA}

http://www.dsm5.org

http://www.adhd.com

http://www.hcp.med.harvard.edu/ncs/asrs.php

http://www.divacenter.eu/content

http://www.ads-bei-erwaschsenen.de/

\section{AKTY PRAWNE}

Rozporządzenie Parlamentu Europejskiego i Rady (UE) 2016/679 z dnia 27 kwietnia 2016 r. w sprawie ochrony osób fizycznych w związku z przetwarzaniem danych 
osobowych i w sprawie swobodnego przepływu takich danych oraz uchylenia dyrektywy 95/46/WE (ogólne rozporządzenie o ochronie danych)

Ustawa o ochronie danych osobowych (Dz. U. 2016 r. poz. 922)

\title{
SOCIAL MALADJUSTMENT IN ADULTS WITH ADHD - DIAGNOSTIC ASPECTS
}

\begin{abstract}
The aim of the presented review is to highlight particular symptoms of ADHD in adults and the relationship between childhood ADHD and adult delinquency. It presents the modifications of diagnostic criteria and methods based upon them. The use of screening methods only causes overestimated or underestimated prevalence of ADHD in adults, therefore a reliable psychiatric diagnosis is necessary. In adults with ADHD there are often additional disorders such as: conduct disorders, emotional disorders, alcohol and/or drug addictions, personality disorders and strong difficulties in everyday functioning. Results of the research on relationship between appearance of ADHD and delinquency suggest that it exists only in the case of severe ADHD demanding pharmacological treatment. In other cases this problem should be analysed in the context of comorbidity and life experiences. It is necessary to prepare a diagnostic guidebook in the field of adult ADHD.
\end{abstract}

Keywords: ADHD, adult, epidemiology, delinquency, conduct disorder, diagnosis 